\title{
Circulating insulin-like growth factor $I$ is involved in the effect of diet on peripheral amyloid $\beta$ clearance
}

Raquel Herrero-Labrador

Cajal Institute

Angel Trueba-Saiz

Cajal Institute

Laura Martinez-Rachadell

Cajal Institute

Maria Estrella Fernandez de Sevilla

Cajal Institute

Jonathan A Zegarra-Valdivia

Cajal Institute

Sonia Diaz-Pacheco

Cajal Institute

Ana M Fernandez

Cajal Institute

Ignacio Torres Aleman ( $\nabla$ torres@cajal.csic.es)

Cajal Institute https://orcid.org/0000-0001-8107-7947

\section{Research}

Keywords: Diet; A $\beta$ clearance; IGF-l; Alzheimer disease

Posted Date: August 21st, 2020

DOI: https://doi.org/10.21203/rs.3.rs-60930/v1

License: (a) (i) This work is licensed under a Creative Commons Attribution 4.0 International License.

Read Full License 


\section{Abstract}

\section{Background}

Obesity is a risk factor for Alzheimer's disease (AD), but underlying mechanisms are not clear.

\section{Methods}

We analyzed peripheral clearance of amyloid $\beta(A \beta)$ in overweight mice because its systemic elimination may impact on brain $A \beta$ load, a major landmark of $A D$ pathology. We also analyzed whether circulating insulin-like growth factor I (IGF-I) intervenes in the effects of overweight as this growth factor modulates brain $A \beta$ clearance, and is increased in serum of overweight mice.

\section{Results}

Overweight mice showed increased peripheral $A \beta$ clearance by the liver, the major site of elimination of systemic $A \beta$, but unaltered brain $A \beta$ levels. We also found that $A \beta$ clearance by hepatocytes is stimulated by IGF-I, and that mice with low serum IGF-I levels show reduced peripheral $A \beta$ clearance and unchanged brain $A \beta$ levels. In the brain, IGF-I favored association of its receptor (IGF-IR) with $A \beta$ precursor protein (APP), and at the same time stimulated non-amyloidogenic processing of APP in astrocytes, as indicated by an increased SAPPa/sAPP $\beta$ ratio after IGF-I treatment. Since serum IGF-I enters into the brain in an activity-dependent manner, we analyzed in overweight mice the effect of brain activation by environmental enrichment (EE) on brain IGF-IR phosphorylation and its association to APP, as a readout of IGF-I activity. After EE, significantly reduced brain IGF-IR phosphorylation and APP/IGF-IR association was found in overweight mice as compared to lean controls.

\section{Conclusions}

Collectively, these results indicate that diet influences peripheral clearance of $A \beta$ without affecting brain $A \beta$ load. Increased serum IGF-I likely contributes to enhanced peripheral A $\beta$ clearance in overweight mice, without affecting brain $A \beta$ clearance probably because its brain entrance is reduced.

\section{Background}

Obesity is considered a risk factor for AD [1-3]. However, the relationship between body weight and dementia appears complex [4-6], and recent observations even pose a protective role of late-life excess weight in AD [7]. Taking into account the worrying worldwide prevalence of obesity and dementia $[8,9]$, greater knowledge of possible links between the two conditions is imperative. Amyloid $\beta(A \beta)$ handling 
may be one such link, as this peptide is considered a major pathogenic factor in AD and obesityassociated inflammation [10] may interfere with its elimination from the brain.

We recently proposed that insulin peptides such as insulin and insulin-like growth factor I (IGF-I), may be involved in the connection between life-style and $A D$ risk [11], although apparently contradictory evidence links IGF-I with AD [12,13]. Significantly, the actions of IGF-I on the brain are modulated by diet [14]. Brain IGF-I is in part locally synthesized [15], and in part derived from uptake from the circulation [16]. The entrance of circulating IGF-I into the brain is activity-dependent and tightly regulated [17], probably because it participates in many essential brain functions [18].

IGF-I may not only be involved in brain A 3 clearance [12]; other findings point to an effect of IGF-I on APP processing towards the non-amyloidogenic pathway, reducing in this way its production [19-21]. However, IGF-I has also been shown to favor the amyloidogenic pathway [22, 23], while a deleterious effect of IGF-I signaling in proteostasis, favoring $A \beta$ accumulation, has also been reported [13]. Of note, hepatocytes, the main source of circulating IGF-I [24], are the major disposal system for circulating A $\beta$ in mice [25], and previous evidence has shown that insulin, a hormone closely related to IGF-I, favors A $\beta$ uptake by hepatocytes [26].

In the present work we investigated regulation of peripheral $A \beta$ clearance in overweight mice, its impact on brain $A \beta$ levels, and the role of circulating IGF-I.

\section{Materials And Methods}

Materials. Human IGF-I was purchased from PeProTec (UK). Primary antibodies were monoclonal antiIGF-I receptor (1:1000; Santa Cruz Biotechnology, USA), monoclonal anti-APP (Nt 22C11; Millipore; 1:200), for PLA studies, polyclonal anti-APP (Sigma; 1:200), for immunoprecipitation, and monoclonal anti-pTyr (1:1000, Transduction Labs, USA). Secondary antibodies were goat anti-rabbit (1:20000) or mouse IRDyecoupled (1:20000), both from LI-COR (USA).

Animals. Male adult (3-5 months old) and new-born wild type C57BL6/J mice, and adult liver IGF-I deficient mutant mice (LID mice; bred in-house, congenic with C57/BL6/J) were used. LID mice present low levels of serum IGF-I due to the disruption of the liver IGF-I gene with the albumin-Cre/Lox system [24]. Serum IGF-I deficient mice have normal body and brain weights and they do not show any major developmental defects $[24,27]$. Animal procedures followed European $(86 / 609 /$ EEC \& 2003/65/EC, European Council Directives) and approval of the local Bioethics Committee.

High fat diet. Wild type C57BL6/J mice were fed for 10 weeks with either a control diet (ref E15000-04), or a high fat diet (HFD) with $45 \% \mathrm{KJ}$ fat $+1.25 \%$ cholesterol (ref E15744-34), both purchased from ssniff Spezialdiäten $\mathrm{GmbH}$ (Germany). After 10 weeks, animals were overweighed (Suppl Fig A), developed glucose intolerance (Supp Fig B), together with hyperinsulinemia and insulin resistance (not shown). 
Cell cultures. Astroglial cultures with $>95 \%$ GFAP-positive cells were prepared as described [28]. Postnatal (day 1-2) brains were dissected, forebrain removed, and mechanically dissociated. The resulting mixed cell suspension was centrifuged and plated in DMEM/F-12 (Life Technologies) with 10\% fetal bovine serum (Life Technologies) and $100 \mathrm{mg} / \mathrm{ml}$ of antibiotic-antimycotic solution (Sigma-Aldrich, Spain). When confluent, cells were shaken $\left(210 \mathrm{rpm} / 37^{\circ} \mathrm{C} / 3\right.$ hours $)$ to detach microglial cells. For microglial cultures, supernatants were centrifuged (1000 rpm/5 min), re-suspended in DMEM/F12 (Life Technologies) + FBS (Gibco, USA), HS and penicillin/streptomycin solution. Cells were seeded at 12.5$10^{4} \mathrm{cells} / \mathrm{cm}^{2}$ in a multi-well coated with poly-L-lysine [29], and cultured for 2 days. Cells were then changed to DMEM/F12 for 3 hours until $A \beta$ uptake was carried out (see below). Astrocytes were then collected from the same flasks that microglia was obtained, as follows. After removing the microgliacontaining supernatant, the medium was replaced and flasks shaken for $15 \mathrm{~h} / 280 \mathrm{rpm}$. Cells were then trypsinized and seeded at $3.75 \times 10^{4}$ cells $/ \mathrm{cm}^{2}$ in the same culture medium, replaced every 4 days. When $80 \%$ confluency was reached, astrocytes were cultured for 3 hours with DMEM/F12 before the different assays were initiated (see below). Endothelial cell cultures were performed as described [29]. Briefly, dissection was performed on ice and cortices were cut into small pieces $\left(1 \mathrm{~mm}^{3}\right)$, digested in a mixture of collagenase/dispase (270 $\mathrm{U}$ collagenase/ml, 10\% dispase) and DNAse $(10 \mathrm{U} / \mathrm{ml})$ in DMEM for $1.5 \mathrm{~h}$ at $37^{\circ} \mathrm{C}$. The cell pellet was separated by centrifugation in $20 \%$ bovine serum albumin/DMEM $(1000 \mathrm{~g}$, $5 \mathrm{~min})$. Capillary fragments were retained on a $10 \mu \mathrm{m}$ nylon filter, removed from the filter with endothelial cell basal medium (Life Technologies), supplemented with $20 \%$ bovine plasma-derived serum and antibiotics (penicillin, $100 \mathrm{U} / \mathrm{ml}$; streptomycin, $100 \mu \mathrm{g} / \mathrm{ml}$ ), and seeded on 60-mm Petri dishes multi-well plate coated with collagen type IV $\left(5 \mu \mathrm{g} / \mathrm{cm}^{2}\right)$ and fibronectin $\left(1 \mu \mathrm{g} / \mathrm{cm}^{2}\right) .3 \mu \mathrm{g} / \mathrm{mL}$ puromycin was added for 3 days, removed from the culture medium and replaced by fibroblast growth factor $(2 \mathrm{ng} / \mathrm{ml})$ and hydrocortisone $(1 \mu \mathrm{g} / \mathrm{ml})$. For hepatocytes cultures, adult ( 2 months old) control animals were anesthesized (pentobarbital $50 \mathrm{mg} / \mathrm{kg}$ ), and the hepatic portal vein exposed to inject a solution containing $\mathrm{NaCl}(118 \mathrm{Mm}), \mathrm{KCl}(4.7 \mathrm{Mm}), \mathrm{KH}_{2} \mathrm{PO}_{4}(1.2 \mathrm{Mm}), \mathrm{NaHCO}_{3}(25 \mathrm{Mm})$, glucose (5.5 Mm), and EGTA $(0.5 \mathrm{Mm})$ at $37 \mathrm{C}$. The inferior cava vein was cut to open the circuit. Thereafter the same solution without EGTA and containing $\mathrm{CaCl}_{2}(2 \mathrm{Mm}), \mathrm{MgSO}_{4}(1.2 \mathrm{Mm})$, and colagenase $(90 \mathrm{U} / \mathrm{ml})$ was perfused. The liver was dissected and placed in DMEM/F12 -10\% FBS with penicillin/ streptomycin, filtered in a 70 um Nylon mesh, centrifuged (60 g, 5 min) and re-suspended in DMEM/F12-10\% FBS with 45\% Percoll (Sigma Aldrich). Cells were then re-suspended and washed 3X in DMEM/F12-10\% FBS using $200 \mathrm{~g}$, 10 min spins, before plating them at $8.25 \times 10^{4}$ cells/collagen-coated multi-well. Cultures were kept 2 days before use.

Glucose tolerance test (GTT). Mice were fasted for 6 hours and left isolated in individual cages (with water but no food access) for at least 30 min before starting the test to avoid any stress-related effect on glycemia [30]. For the glucose tolerance test (GTT), an overload of glucose $(2 \mathrm{~g} / \mathrm{kg})$ was injected intraperitoneally. The aqueous solution was left overnight at room temperature so the $\beta$-form of glucose was enriched. Blood samples were extracted from the tip of the tail at time $0,15,30,60$, and 90 to measure glucose levels with a glucometer (Menarini Diagnosis, Italy). 
Environmental enrichment. Mice were submitted to environmental enrichment as explained in detail elsewhere [31]. Briefly, animals were placed for 2 hours in a large cage, 10 animals/cage and with different objects (cardboard tunnels, shelters of different materials, a plastic net, toys, chewable and nesting material). Thereafter, they were sacrificed and their brain collected for immunoprecipitation and western blot analysis.

A $\beta$ uptake. In vitro: Cells were treated during 15 hours with $500 \mathrm{nM}$ soluble $A \beta 40-$ HiLyte Fluor $^{\text {TM }} 488$ (AnaSpec) [32], and IGF-I (1 nM in glial cultures, $10 \mathrm{nM}$ in hepatocytes). Thereafter, cultures were washed with PBS pH 6.0 to eliminate membrane bound A $\beta$ followed by PBS pH 7.4. Cell nuclei were stained with Hoechst 33342 (Thermo Fisher Scientific; 1:500) in PBS pH 7.4/5 min, fluorescent images were taken in an DMI 6000 (Leica) microscope using Exc: 350 nm/ Em: 461 nm for Hoeschst dye and Exc: 503 nm/ Em: $528 \mathrm{~nm}$ for fluorescently labeled $A \beta$. Thereafter, cells were lysed in Tris- $\mathrm{HCl}(10 \mathrm{mM}) \mathrm{pH}$ 8.0, guanidine $(50 \mathrm{mM})$, and spinned at $14.000 \mathrm{rpm}$ for $10 \mathrm{~min}$ at $4^{\circ} \mathrm{C}$. Fluorescence was quantified in a FLUOStar OPTIMA (BMG Labtech) at Exc: $485 \mathrm{~nm} / \mathrm{Em}: 520 \mathrm{~nm}$. In transcytosis assays using brain endothelial cells, Aß40-HiLyte Fluor ${ }^{\mathrm{TM}} 488$ soluble ( $500 \mathrm{nM}$ ) was added in the bottom compartment (Fig. 4C) with or without $1 \mathrm{nM} \mathrm{IGF-I,} \mathrm{and} \mathrm{after} 15$ hours the culture medium from the upper chamber was collected and fluorescence measured in the fluorimeter, as above.

\section{In vivo}

A 340 -HiLyte Fluor ${ }^{\text {TM }} 488(400 \mu \mathrm{g} / \mathrm{kg})$ was injected into the tail vein using a $0.38 \mathrm{~mm}$ cannula (Intramedic, Spain), and after 90 min mice were sacrificed, blood taken from the heart and liver dissected. Liver tissue was homogenized in Tris- $\mathrm{HCl}(10 \mathrm{mM}) \mathrm{pH} 8.0$ - guanidine $(50 \mathrm{mM})$. Fluorescence in serum and liver extracts was quantified by fluorimetry, as above. Values were normalized per $\mathrm{ml}$ of serum or $\mathrm{mg}$ of protein. The latter was measured in liver samples using the BCA system (Sigma).

Immunoassays. Western blot and immunoprecipitation were performed as described elsewhere in detail [33]. Densitometric analysis of blots was performed using the Odissey system (Lycor Biosciences, USA). A representative blot is shown from a total of at least three independent experiments. GFAP immunocytochemistry in cultured cells followed previously published procedures [33]. In brief, cultured cells were incubated to block non-specific antibody binding, followed by incubation overnight at $4{ }^{\circ} \mathrm{C}$ with anti-GFAP in phosphate buffer (PB) - 1\% bovine albumin - 1\% Triton X-100 (PBT). After several washes in $\mathrm{PB}$, sections were incubated with an Alexa-coupled secondary antibody (1:1000, Molecular Probes, USA) diluted in PBT. Finally, a 1:500 dilution (in PBS) of DAPI (Hoechst 33342) was added for 3 minutes. Wells were rinsed several times in PB $0.1 \mathrm{~N}$, mounted with $15 \mu \mathrm{l}$ of gerbatol mounting medium, and allowed to dry. Omission of primary antibody was used as control. Microphotographs were taken in a Leica (Germany) microscope. Plaque load was determined as explained elsewhere in detail [33].

IGF-I in serum and brain was determined using a species-specific ELISA (R\&D Systems, USA), as described in detail elsewhere [18]. Murine A $\beta$ (Thermofisher, USA), and murine SAPPa and SAPP $\beta$ were determined by ELISA in brain lysates and culture supernatants, respectively, following the manufacturer's 
instructions. Blood was collected from the heart after pentobarbital anesthesia and thereafter brains were dissected and frozen at $-80^{\circ} \mathrm{C}$ until used.

Proximity ligation assays (PLA). Assays were performed as described [34]. Amyloid precursor protein (APP) - IGF-IR interactions were detected in astrocytes and neurons grown on glass coverslips using the Duolink II in situ PLA detection Kit (OLink; Bioscience, Sweden). Cultured cells were fixed in $4 \%$ paraformaldehyde/10 min, washed with PBS containing $20 \mathrm{mM}$ glycine to quench the aldehyde groups, permeabilized with the same buffer containing $0.05 \%$ Triton X-100 for $5 \mathrm{~min}$, and washed with PBS. After $1 \mathrm{~h} / 37^{\circ} \mathrm{C}$ with the blocking solution in a pre-heated humidity chamber, cells were incubated overnight in antibody diluent medium with primary antibodies: mouse monoclonal anti-APP and rabbit polyclonal anti-IGF-I receptor, and processed following the instructions of the supplier using the PLA probes detecting rabbit or mouse antibodies (Duolink II PLA probe anti-Rabbit plus, and Duolink II PLA probe antiMouse minus, diluted 1:5 in antibody diluent), and a DAPI-containing mounting medium.

Statistical analysis. Normal distribution tests were carried out in all experiments and a non-parametric Wilcoxon test was applied accordingly. For samples with normal distribution, parametric tests include one-way ANOVA followed by a Bonferroni or $\mathrm{t}$-test. A $\mathrm{p}<0.05$ was considered significant.

\section{Results}

\section{Diet influences peripheral $A \beta$ clearance}

We examined peripheral $A \beta$ disposal in overweight mice because is a proposed mechanism for central $A \beta$ clearance [35]. We administered fluorescently tagged $A \beta$ to mice fed with a high fat diet (HFD) for 10 weeks. Animals became overweight and glucose intolerant (Suppl Figure A,B). Ninety minutes after intravenous injection of $A \beta$, overweight mice showed significantly increased fluorescence accumulation in the liver and decreased in serum, suggesting increased disposal of $A \beta$ through hepatocytes (Fig. 1A). Conversely, brain A $\beta$ levels in overweight mice were not different from those seen in lean ones (Fig. 1B).

\section{IGF-I promotes Ab uptake by hepatocytes}

To try to clarify the discrepancy between increased peripheral disposal of Ab and normal brain Ab load, we analyzed a possible role of IGF-I, that is mostly produced by the liver [24], and is increased in overweight mice (Figure 2A). We determined whether IGF-I modulates uptake of Ab by hepatocytes, as a read-out of its clearance by this liver cell. As shown in Figure 2B, in the presence of IGF-I (10 nM), hepatocytes accumulated significantly more fluorescence, suggesting a stimulatory action of IGF-I on Ab uptake by these cells. Moreover, liver IGF-I deficient (LID) mice with a 70\% reduction in circulating IGF-I [36], showed reduced liver accumulation of tagged Ab after intravenous injection, while blood levels were increased, as compared to controls, indicating reduced liver clearance (Figure 2C). However, as in overweight mice, LID mice did not show changes in brain Ab levels (Figure 2D).

\section{Cell-specific actions of IGF-I in APP metabolism by brain cells}


IGF-I has been reported to promote either amyloidogenic [22], or non-amyloidogenic [20] APP processing pathways in neuronal cell lines. To clarify its role in primary cells, we analyzed the actions of IGF-I on amyloidogenic and non-amyloidogenic APP processing by astrocytes and neurons, the primary sources of $A b$ in the brain $[37,38]$. Using the soluble APP metabolites sAPPb and SAPPa as markers of the amyloidogenic and the non-amyloidogenic pathway, respectively, we found that IGF-I modulates their production in a cell specific fashion. In astrocytes, secretion of both soluble forms of APP was stimulated by IGF-I, whereas in neurons IGF-I inhibited their secretion (Figure 3A). However, the APPa/sAPPb ratio was increased in both cell types, indicating that the net action of IGF-I is to promote non-amyloidogenic processing of APP (Figure 3B).

Since both IGF-IR and APP associate to LRP1, and APP processing depends on its subcellular localization [39], we assessed whether IGF-IR and APP interact with each other. Indeed, IGF-IR and APP coimmunoprecipitated in astrocytes, whereas in neurons the interaction was negligible (Figure 3C). Proximity ligation assays (PLA) confirmed a robust interaction of APP with IGF-IR in astrocytes (Figure 3D), while in neurons the interaction was negligible (not shown). Treatment of astrocytes with IGF-I resulted in a significantly increased interaction between both proteins, as determined by a stronger PLA signal (Figure 3D).

Since IGF-I promotes Ab uptake by hepatocytes [40], we examined whether it can exert similar action in brain cells. In this organ, the main cell types involved in Ab clearance are microglia and astrocytes through its uptake and degradation [41, 42], and endothelial cells at the blood-brain-barrier (BBB), through efflux of brain $A b$ into the circulation [43]. We found that IGF-I promoted Ab uptake by astrocytes (Figure 4A), while decreased it in microglia (Figure 4B). In brain endothelial cell cultures mimicking the BBB architecture [17], IGF-I not significantly inhibited Ab efflux from the "brain" side to the "blood" side of the double chamber (Figure 4C).

\section{Reduced brain IGF-I activity in overweight mice}

Since serum IGF-I levels are increased in overweight mice (Figure 2A), we determined whether brain IGF-I is correspondingly higher, as serum IGF-I crosses the BBB [16]. However, overweight mice showed normal brain IGF-I levels (Figure 5A). To explain this discrepancy between peripheral and central IGF-I levels, we determined whether passage of serum IGF-I into the brain is reduced in overweight mice. To this end, we took advantage that exposure to environmental enrichment (EE) stimulates the passage of serum IGF-I into the brain [17]. We tested whether overweight mice show altered passage of IGF-I after EE by measuring Tyr-phosphorylation of brain IGF-I receptors as a proxy of their activity. After EE, overweight mice showed reduced IGF-IR phosphorylation (Figure 5B), pointing to impaired entrance of circulating IGF-I. In addition, since systemic administration of IGF-I to lean mice housed under standard conditions showed enhanced APP/IGF-IR interaction (Figure 5C), corroborating in vitro observations (Figure 3D), we used this interaction as an additional indicator of the entrance of IGF-I into the brain of EE-stimulated overweight mice. Significantly, whereas in lean mice EE produced enhanced brain APP/IGF-IR 
interactions, in overweight mice, this interaction was significantly smaller (Figure 5D), pointing to reduced entrance of IGF-I.

\section{Discussion}

These results indicate that in adult normal mice, diet influences peripheral $A \beta$ clearance through the liver and that circulating IGF-I may play a role in this effect. Of note, either increases or decreases in peripheral $A \beta$ clearance did not impact on brain $A \beta$ levels. $A$ lack of correlation between peripheral and central $A \beta$ clearance agrees with observations that reducing peripheral $A \beta$ does not affect brain $A \beta$ levels, or with no correlation of central and peripheral $A \beta$ levels in $A D$ patients [44-47]. Compartmentalization of $A \beta$ clearance may be reflecting multiple sources of this circulating peptide, as under normal physiological circumstances, $A \beta$ is produced not only in the brain, but throughout the body.

However, other observations do not support compartmentalization of $A \beta$ clearance. Thus, increased peripheral $A \beta$ levels after anti-A $\beta$ treatment was reported to parallel a decrease of brain $A \beta$; reducing peripheral $A \beta$ was sufficient to reduced brain $A \beta$, and recent studies favor a diagnostic utility of the relationship between plasma and $\operatorname{CSF} A \beta_{1-42}[35,48,49]$. Thus, the relationship between peripheral and central $A \beta$ is still under debate [50]; indeed, a substantial part of brain $A \beta$ clearance in humans takes place in the periphery [51].

In turn, normal brain levels of $A \beta$ in overweight mice agree with previously reported similar observations [52], but not with increased brain $A \beta$ load found by others [53,54]. Conversely, enhanced elimination of circulating $A \beta$ in overweight mice favors the notion that higher body mass index may be protective rather than detrimental for AD risk [4], However, unaffected brain A $\mathrm{B}$ load does not fit with a protective effect of increased body mass, unless still undefined systemic changes contribute to $A D$, as recently postulated [55].

Among the latter, we considered circulating IGF-I as a probable systemic factor influencing the connection of obesity with AD. IGF-I is involved in brain $A \beta$ clearance [12] -although this has been questioned [56], and shows diet-sensitive actions in the brain [14]. Indeed, several observations favor an involvement of circulating IGF-I in the systemic pro-clearance actions of a high fat diet. 1) IGF-I levels are increased in overweight mice, 2) IGF-I, as previously seen with insulin [26], stimulates uptake of $A \beta$ by hepatocytes, and 3) LID mice with low serum IGF-I show reduced peripheral A $\beta$ clearance. Thus, higher serum IGF-I levels in overweight mice may contribute to reduce peripheral $A \beta$ levels, without affecting brain $A \beta$ load. The latter disagrees with our previous observation of increased brain A $\beta$ levels in LID mice [12]. The use of an in-house ELISA and formic acid extraction of total brain A $\beta$ (prior results) vs a commercial ELISA with guanidinium $\mathrm{HCl}$ extraction of brain $A \beta$ (current results), or changing housing conditions of LID mice along time in our animal facility (i.e.: sterile food pellets) affecting their microbiome [57], that shows strong interactions with IGF-I function [58], may explain this discrepancy, but we do not have a straightforward explanation of this important difference with our previous results. 
As indicated by an increased SAPPa/SAPP $\beta$ ratio in IGF-I-treated neurons and astrocytes, the net action of IGF-I on the main cell types producing $A \beta$ in the brain is to favor non-amyloidogenic processing of APP, contributing in this way to lower its brain levels and enhance neuroprotection, as SAPPa is neuroprotective acting in part through IGF-IR [59]. Thus, the overall action of IGF-I in the brain may be antiamyloidogenic. Intriguingly, insulin favors $A \beta$ secretion in neurons [60], suggesting a complex interplay of these hormones in regulating brain $A \beta$ levels. At the same time, reduced IGF-I entrance in the brain of overweight mice may hamper its anti-amyloidogenic actions. Indeed, overweight mice showed not only reduced entrance of serum IGF-I in response to EE stimulation, as determined by reduced brain IGF-IR phosphorylation, but also reduced APP/IGF-IR interaction. In previous work we documented an inhibitory effect of triglycerides (TGLs) in BBB entrance of IGF-I across the choroid plexus [14]. It is possible that high serum TGLs as a result of the high fat diet interfere also with the BBB entrance of IGF-I across brain endothelial cells in overweight mice, as previously seen for other circulating hormones such as insulin [61] or leptin [62].

Reduced IGF-I entrance would affect its pro-clearance actions on brain $A \beta[12,63]$. Also, we cannot discard that the inhibitory actions of IGF-I on $A \beta$ uptake by microglia may also counteract its actions on astrocytes (but see below). Alternatively, brain $A \beta$ levels may not be affected by peripheral $A \beta$ clearance or other factors may also contribute to it, such as the recently postulated vascular drainage [64, 65]. Interestingly, insulin also enhances the degradation of $A \beta$ and its clearance in astrocytes [66], and hepatocytes [26], respectively. Thus, these two closely related hormones may modulate $A \beta$ disposal in a concerted manner, as previously reported for glucose handling [67].

IGF-I stimulates $A \beta$ uptake by astrocytes, while inhibits it in microglia. Whereas astrocytes appear critical to determine $A \beta$ load [68], and increased clearance of $A \beta$ by astrocytes may result in reduced $A \beta$ plaques [42], inhibition of $A \beta$ uptake by microglia may also reduce plaques [69], as the role of microglial uptake of $A \beta$ in plaque formation may be detrimental $[70,71]$. In accordance with a stimulatory effect of IGF-I on astrocytes, previous observations suggested that astrocyte-derived IGF-I protects neurons against $A \beta$ toxicity through a mechanism involving its uptake [72].

The observed astrocyte-specific interaction of APP with IGF-IR and on SAPPa and SAPP $\beta$ levels may be related to a differential processing of APP by IGF-I in these cells, since its processing depends on its intracellular localization [39]. Of the different isoforms of APP, the major one expressed in neurons is $\mathrm{APP}_{695}$, that lacks the extracelular protein-protein interaction domain KPI. This domain is present in the longer isoforms, $\mathrm{APP}_{751}$ and $\mathrm{APP}_{770}$, that are the most abundant types in glial cells [73]. It is possible that $\mathrm{KPI}$ is involved in the observed interactions with IGF-IR in astrocytes, but this requires further analysis. In turn, a trend of IGF-I to inhibit brain efflux of $A \beta$ through BBB endothelial cells, would favor its accumulation in brain parenchyma [74]. We previously reported that IGF-I stimulates A $\beta$ efflux through the choroid plexus BBB [12], an observation supported by the reducing effects of in vivo IGF-I administration on brain $A \beta$ levels $[12,63]$. Thus, IGF-I may show site-specific effects on $A \beta$ efflux through $B B B$ cells.

\section{Limitations}


An important limitation of this study is that we determined peripheral Ab clearance indirectly. Measuring dynamic changes in circulating levels of $A b$ in overweight mice would be necessary to firmly establish that peripheral Ab clearance is enhanced. However, available methods of quantification of serum $A b$ are not sensitive enough to reliably detect decreases in non-transgenic mice.

\section{Conclusions}

In summary, diet influences peripheral, but not central $A \beta$ clearance. A lack of correlation between peripheral clearance and central $A \beta$ load further support a non-linear relationship between both compartments. Actions of IGF-I on $A \beta$ handling may be related to diet influences on $A D$ pathology; therefore cellular sites of IGF-I interaction may constitute new druggable targets, through, for example, potentiating the passage of circulating IGF-I into the brain across the BBB.

\section{Declarations}

\section{Ethical approval}

This work was carried out in mice after receiving the approval of the Ethics Committee, as indicated in the manuscript

\section{Consent for publication}

Not applicable

\section{Availability of data and materials}

The datasets used and/or analyzed during the current study are available from the corresponding author on reasonable request.

\section{Competing interests}

The authors have no conflicts of interest to declare

Funding This work was funded by a grant from Ciberned, by an Inter-CIBER project (PIE14/00061), and from SAF2013-40710-R (AEI/FEDER, UE). J.A. Zegarra-Valdivia acknowledges the financial support of the National Council of Science, Technology and Technological Innovation (CONCYTEC, Perú) through the National Fund for Scientific and Technological Development (FONDECYT, Perú).

\section{Authors contributions}

$\mathrm{RH}$ performed experiments, analyzed results, and wrote part of the manuscript. ATS performed experiments and analyzed results. LMR performed experiments and analyzed results. EFS performed 
experiments and analyzed results. JAZV and SDP helped with experiments. AMF performed experiments and analyzed results. ITA designed the study, analyzed results, and wrote the manuscript.

\section{Acknowledgements}

We are thankful to M. Garcia and R. Cañadas for technical support.

\section{References}

1. Kivimaki M, Luukkonen R, Batty GD, Ferrie JE, Pentti J, Nyberg ST, Shipley MJ, Alfredsson L, Fransson $\mathrm{El}$, Goldberg $\mathrm{M}$, et al: Body mass index and risk of dementia: Analysis of individual-level data from 1.3 million individuals. Alzheimers Dement 2018, 14(5):601-609.

2. Profenno LA, Porsteinsson AP, Faraone SV. Meta-analysis of Alzheimer's disease risk with obesity, diabetes, and related disorders. Biol Psychiatry. 2010;67(6):505-12.

3. Singh-Manoux A, Dugravot A, Shipley M, Brunner EJ, Elbaz A, Sabia S, Kivimaki M. Obesity trajectories and risk of dementia: 28 years of follow-up in the Whitehall II Study. Alzheimers Dement. 2018;14(2):178-86.

4. Lee CM, Woodward M, Batty GD, Beiser AS, Bell S, Berr C, Bjertness E, Chalmers J, Clarke R, Dartigues $\mathrm{J}-\mathrm{F}$, et al. Association of anthropometry and weight change with risk of dementia and its major subtypes: A meta-analysis consisting 2.8 million adults with 57294 cases of dementia. Obes Rev. 2020. 10.1111/obr.12989.

5. Dye L, Boyle NB, Champ C, Lawton C. The relationship between obesity and cognitive health and decline. Proc Nutr Soc. 2017;76(4):443-54.

6. Jimenez A, Pegueroles J, Carmona-Iragui M, Vilaplana E, Montal V, Alcolea D, Videla L, Illan-Gala I, Pane A, Casajoana A, et al. Weight loss in the healthy elderly might be a non-cognitive sign of preclinical Alzheimer's disease. Oncotarget. 2017;8(62):104706-16.

7. Sun Z, Wang Z-T, Sun F-R, Shen X-N, Xu W, Ma Y-H, Dong Q, Tan L, Yu J-T. Alzheimer's Disease Neuroimaging I: Late-life obesity is a protective factor for prodromal Alzheimer's disease: a longitudinal study. Aging. 2020;12(2):2005-17.

8. Scheltens P, Blennow K, Breteler MM, de Strooper B, Frisoni GB, Salloway S. Van der Flier WM: Alzheimer's disease. Lancet. 2016;388(10043):505-17.

9. Engin A. The Definition and Prevalence of Obesity and Metabolic Syndrome. Adv Exp Med Biol. 2017;960:1-17.

10. Cox AJ, West NP, Cripps AW. Obesity, inflammation, and the gut microbiota. Lancet Diabetes Endocrinol. 2015;3(3):207-15.

11. Fernandez AM, Santi A, Torres Aleman I. Insulin Peptides as Mediators of the Impact of Life Style in Alzheimer's disease. Brain plasticity (Amsterdam Netherlands). 2018;4(1):3-15. 
12. Carro E, Trejo JL, Gomez-Isla T, LeRoith D, Torres-Aleman I. Serum insulin-like growth factor I regulates brain amyloid-beta levels. Nat Med. 2002;8(12):1390-7.

13. Cohen E, Paulsson JF, Blinder P, Burstyn-Cohen T, Du D, Estepa G, Adame A, Pham HM, Holzenberger M, Kelly JW, et al. Reduced IGF-1 signaling delays age-associated proteotoxicity in mice. Cell. 2009;139(6):1157-69.

14. Dietrich MO, Muller A, Bolos M, Carro E, Perry ML, Portela LV, Souza DO, Torres-Aleman I. Western Style Diet Impairs Entrance of Blood-Borne Insulin-like Growth Factor-1 into the Brain.

Neuromolecular Med. 2007;9(4):324-30.

15. Bach MA, Shen-Orr Z, Lowe WL Jr, Roberts CT Jr, LeRoith D. Insulin-like growth factor I mRNA levels are developmentally regulated in specific regions of the rat brain. Brain Res Mol Brain Res. 1991;10(1):43-8.

16. Carro E, Nunez A, Busiguina S, Torres-Aleman I. Circulating insulin-like growth factor I mediates effects of exercise on the brain. J Neurosci. 2000;20(8):2926-33.

17. Nishijima T, Piriz J, Duflot S, Fernandez AM, Gaitan G, Gomez-Pinedo U, Verdugo JM, Leroy F, Soya H, Nunez A, et al. Neuronal activity drives localized blood-brain-barrier transport of serum insulin-like growth factor-I into the CNS. Neuron. 2010;67(5):834-46.

18. Trejo JL, Piriz J, Llorens-Martin MV, Fernandez AM, Bolos M, LeRoith D, Nunez A, Torres-Aleman I. Central actions of liver-derived insulin-like growth factor I underlying its pro-cognitive effects. Mol Psychiatry. 2007;12(12):1118-28.

19. Jacobsen KT, Adlerz L, Multhaup G, Iverfeldt K. Insulin-like growth factor-1 (IGF-1)-induced processing of amyloid-\{beta\} precursor protein (APP) and APP-like protein 2 is mediated by different metalloproteinases. J Biol Chem. 2010;285:10223-31.

20. Adlerz L, Holback S, Multhaup G, Iverfeldt K. IGF-1-induced processing of the amyloid precursor protein family is mediated by different signaling pathways. J Biol Chem. 2007;282(14):10203-9.

21. Zhang H, Gao Y, Dai Z, Meng T, Tu S, Yan Y. IGF-1 reduces BACE-1 expression in PC12 cells via activation of PI3-K/Akt and MAPK/ERK1/2 signaling pathways. Neurochem Res. 2011;36(1):49-57.

22. Araki W, Kume H, Oda A, Tamaoka A, Kametani F. IGF-1 promotes beta-amyloid production by a secretase-independent mechanism. Biochem Biophys Res Commun 2009.

23. Costantini C, Scrable H, Puglielli L. An aging pathway controls the TrkA to p75NTR receptor switch and amyloid beta-peptide generation. EMBO J. 2006;25(9):1997-2006.

24. Yakar S, Liu JL, Stannard B, Butler A, Accili D, Sauer B, LeRoith D. Normal growth and development in the absence of hepatic insulin-like growth factor I. Proc Natl Acad Sci U S A. 1999;96(13):7324-9.

25. Ghiso J, Shayo M, Calero M, Ng D, Tomidokoro Y, Gandy S, Rostagno A, Frangione B. Systemic Catabolism of Alzheimer's A\{beta\}40 and A\{beta\}42. J Biol Chem. 2004;279(44):45897-908.

26. Tamaki C, Ohtsuki S, Terasaki T. Insulin facilitates the hepatic clearance of plasma amyloid betapeptide (140) by intracellular translocation of low-density lipoprotein receptor-related protein 1 (LRP1) to the plasma membrane in hepatocytes. Mol Pharmacol. 2007;72(4):850-5. 
27. Sjogren K, Jansson JO, Isaksson OG, Ohlsson C. A transgenic model to determine the physiological role of liver-derived insulin-like growth factor I. Minerva Endocrinol. 2002;27(4):299-311.

28. Fernandez AM, Fernandez S, Carrero P, Garcia-Garcia M, Torres-Aleman I. Calcineurin in reactive astrocytes plays a key role in the interplay between proinflammatory and anti-inflammatory signals. J Neurosci. 2007;27(33):8745-56.

29. Trueba-Saiz A, Fernandez AM, Nishijima T, Mecha M, Santi A, Munive V, Torres-Aleman I. Circulating Insulin-like Growth Factor I Regulates Its Receptor in the Brain of Male Mice. Endocrinology. 2017;158:349-57.

30. Ayala JE, Samuel VT, Morton GJ, Obici S, Croniger CM, Shulman GI, Wasserman DH, McGuinness OP, Consortium NIHMMPC. Standard operating procedures for describing and performing metabolic tests of glucose homeostasis in mice. Dis Model Mech. 2010;3(9-10):525-34.

31. Trueba-Saiz A, Cavada C, Fernandez AM, Leon T, Gonzalez DA, Fortea OJ, Lleo A, Del ST, Nunez A, Torres-Aleman I. Loss of serum IGF-I input to the brain as an early biomarker of disease onset in Alzheimer mice. Transl Psychiatry. 2013;3:e330.

32. Liu CC, Hu J, Zhao N, Wang J, Wang N, Cirrito JR, Kanekiyo T, Holtzman DM, Bu G. Astrocytic LRP1 Mediates Brain Abeta Clearance and Impacts Amyloid Deposition. J Neurosci. 2017;37(15):4023-31.

33. Fernandez AM, Jimenez S, Mecha M, Davila D, Guaza C, Vitorica J, Torres-Aleman I. Regulation of the phosphatase calcineurin by insulin-like growth factor I unveils a key role of astrocytes in Alzheimer's pathology. Mol Psychiatry. 2012;17(7):705-18.

34. Martinez-Rachadell L, Aguilera A, Perez-Domper P, Pignatelli J, Fernandez AM, Torres-Aleman I. Cellspecific expression of insulin/insulin-like growth factor-I receptor hybrids in the mouse brain. Growth Horm IGF Res. 2019;45:25-30.

35. DeMattos RB, Bales KR, Cummins DJ, Dodart JC, Paul SM, Holtzman DM. Peripheral anti-A beta antibody alters CNS and plasma $A$ beta clearance and decreases brain $A$ beta burden in a mouse model of Alzheimer's disease. Proc Natl Acad Sci U S A. 2001;98(15):8850-5.

36. Zegarra-Valdivia JA, Santi A, Fernandez de Sevilla ME, Nunez A, Torres Aleman I. Serum Insulin-Like Growth Factor I Deficiency Associates to Alzheimer's Disease Co-Morbidities. J Alzheimers Dis. 2019;69(4):979-87.

37. Kamenetz F, Tomita T, Hsieh H, Seabrook G, Borchelt D, Iwatsubo T, Sisodia S, Malinow R. APP processing and synaptic function. Neuron. 2003;37(6):925-37.

38. Zhao J, O'Connor T, Vassar R. The contribution of activated astrocytes to Abeta production: implications for Alzheimer's disease pathogenesis. J Neuroinflammation. 2011;8:150.

39. Choy RW, Cheng Z, Schekman R. Amyloid precursor protein (APP) traffics from the cell surface via endosomes for amyloid beta (Abeta) production in the trans-Golgi network. Proc Natl Acad Sci U S A. 2012;109(30):E2077-82.

40. Pietrzik CU, Yoon IS, Jaeger S, Busse T, Weggen S, Koo EH. FE65 constitutes the functional link between the low-density lipoprotein receptor-related protein and the amyloid precursor protein. $\mathrm{J}$ Neurosci. 2004;24(17):4259-65. 
41. Griciuc A, Serrano-Pozo A, Parrado AR, Lesinski AN, Asselin CN, Mullin K, Hooli B, Choi SH, Hyman BT, Tanzi RE: Alzheimer's Disease Risk Gene CD33 Inhibits Microglial Uptake of Amyloid Beta. Neuron 2013.

42. Wyss-Coray T, Loike JD, Brionne TC, Lu E, Anankov R, Yan F, Silverstein SC, Husemann J. Adult mouse astrocytes degrade amyloid-beta in vitro and in situ. Nat Med. 2003;9(4):453-7.

43. Deane R, Wu Z, Sagare A, Davis J, Du YS, Hamm K, Xu F, Parisi M, LaRue B, Hu HW, et al. LRP/amyloid beta-peptide interaction mediates differential brain efflux of Abeta isoforms. Neuron. 2004;43(3):333-44.

44. Walker JR, Pacoma R, Watson J, Ou W, Alves J, Mason DE, Peters EC, Urbina HD, Welzel G, Althage A, et al. Enhanced Proteolytic Clearance of Plasma A+| by Peripherally Administered Neprilysin Does Not Result in Reduced Levels of Brain A+| in Mice. The Journal of Neuroscience. 2013;33(6):245764.

45. Fukumoto H, Tennis M, Locascio JJ, Hyman BT, Growdon JH, Irizarry MC. Age but not diagnosis is the main predictor of plasma amyloid beta-protein levels. Arch Neurol. 2003;60(7):958-64.

46. Mehta PD, Pirttila T, Patrick BA, Barshatzky M, Mehta SP. Amyloid beta protein 1-40 and 1-42 levels in matched cerebrospinal fluid and plasma from patients with Alzheimer disease. Neurosci Lett. 2001;304(1-2):102-6.

47. Siemers ER, Dean RA, Friedrich S, Ferguson-Sells L, Gonzales C, Farlow MR, May PC. Safety, tolerability, and effects on plasma and cerebrospinal fluid amyloid-beta after inhibition of gammasecretase. Clin Neuropharmacol. 2007;30(6):317-25.

48. Albani D, Marizzoni M, Ferrari C, Fusco F, Boeri L, Raimondi I, Jovicich J, Babiloni C, Soricelli A, Lizio $\mathrm{R}$, et al. Plasma Abeta42 as a Biomarker of Prodromal Alzheimer's Disease Progression in Patients with Amnestic Mild Cognitive Impairment: Evidence from the PharmaCog/E-ADNI Study. J Alzheimers Dis. 2019;69(1):37-48.

49. Sutcliffe JG, Hedlund PB, Thomas EA, Bloom FE, Hilbush BS. Peripheral reduction of beta-amyloid is sufficient to reduce brain beta-amyloid: implications for Alzheimer's disease. J Neurosci Res. 2011;89(6):808-14.

50. Bassendine MF, Taylor-Robinson SD, Fertleman M, Khan M, Neely D. Is Alzheimer's Disease a Liver Disease of the Brain? J Alzheimers Dis. 2020;75:1-14.

51. Roberts KF, Elbert DL, Kasten TP, Patterson BW, Sigurdson WC, Connors RE, Ovod V, Munsell LY, Mawuenyega KG, Miller-Thomas MM, et al. Amyloid-beta efflux from the central nervous system into the plasma. Ann Neurol. 2014;76(6):837-44.

52. Zhang L, Dasuri K, Fernandez-Kim SO, Bruce-Keller AJ, Freeman LR, Pepping JK, Beckett TL, Murphy MP, Keller JN. Prolonged diet induced obesity has minimal effects towards brain pathology in mouse model of cerebral amyloid angiopathy: implications for studying obesity-brain interactions in mice. Biochim Biophys Acta. 2013;1832(9):1456-62.

53. Li J, Deng J, Sheng W, Zuo Z. Metformin attenuates Alzheimer's disease-like neuropathology in obese, leptin-resistant mice. Pharmacol Biochem Behav. 2012;101(4):564-74. 
54. Puig KL, Floden AM, Adhikari R, Golovko MY, Combs CK. Amyloid precursor protein and proinflammatory changes are regulated in brain and adipose tissue in a murine model of high fat diet-induced obesity. PLoS One. 2012;7(1):e30378.

55. Wang J, Gu BJ, Masters CL, Wang Y-J. A systemic view of Alzheimer disease - insights from amyloid$\beta$ metabolism beyond the brain. Nature reviews Neurology. 2017;13(10):612-23.

56. Lanz TA, Salatto CT, Semproni AR, Marconi M, Brown TM, Richter KE, Schmidt K, Nelson FR, Schachter JB. Peripheral elevation of IGF-1 fails to alter Abeta clearance in multiple in vivo models. Biochem Pharmacol. 2008;75(5):1093-103.

57. Servick K. Of mice and microbes. Science. 2016;353(6301):741-3.

58. Jensen EA, Young JA, Mathes SC, List EO, Carroll RK, Kuhn J, Onusko M, Kopchick JJ, Murphy ER, Berryman DE. Crosstalk between the growth hormone/insulin-like growth factor-1 axis and the gut microbiome: A new frontier for microbial endocrinology. Growth Hormon IGF Res. 2020;5354:101333.

59. Jimenez S, Torres M, Vizuete M, Sanchez-Varo R, Sanchez-Mejias E, Trujillo-Estrada L, CarmonaCuenca I, Caballero C, Ruano D, Gutierrez A, et al: Age-dependent accumulation of soluble Abeta oligomers reverses the neuroprotective effect of sAPPalpha by modulating PI3K/Akt-GSK-3beta pathway in Alzheimer mice model. J Biol Chem 2011.

60. Gasparini L, Gouras GK, Wang R, Gross RS, Beal MF, Greengard P, Xu H. Stimulation of beta-amyloid precursor protein trafficking by insulin reduces intraneuronal beta-amyloid and requires mitogenactivated protein kinase signaling. J Neurosci. 2001;21(8):2561-70.

61. Kaiyala KJ, Prigeon RL, Kahn SE, Woods SC, Schwartz MW. Obesity induced by a high-fat diet is associated with reduced brain insulin transport in dogs. Diabetes. 2000;49(9):1525-33.

62. Banks WA, Coon AB, Robinson SM, Moinuddin A, Shultz JM, Nakaoke R, Morley JE. Triglycerides induce leptin resistance at the blood-brain barrier. Diabetes. 2004;53(5):1253-60.

63. Carro E, Trejo JL, Gerber A, Loetscher H, Torrado J, Metzger F, Torres-Aleman I. Therapeutic actions of insulin-like growth factor I on APP/PS2 mice with severe brain amyloidosis. Neurobiol Aging. 2006;27(9):1250-7.

64. van Veluw SJ, Hou SS, Calvo-Rodriguez M, Arbel-Ornath M, Snyder AC, Frosch MP, Greenberg SM, Bacskai BJ. Vasomotion as a Driving Force for Paravascular Clearance in the Awake Mouse Brain. Neuron 2019:S0896-6273(0819)30928 - 30926..

65. Iliff JJ, Wang M, Liao Y, Plogg BA, Peng W, Gundersen GA, Benveniste H, Vates GE, Deane R, Goldman SA, et al. A Paravascular Pathway Facilitates CSF Flow Through the Brain Parenchyma and the Clearance of Interstitial Solutes, Including Amyloid +1. Sci TransI Med. 2012;4(147):147ra111-1.

66. Yamamoto N, Ishikuro R, Tanida M, Suzuki K, Ikeda-Matsuo Y, Sobue K. Insulin-signaling Pathway Regulates the Degradation of Amyloid beta-protein via Astrocytes. Neuroscience. 2018;385:227-36.

67. Fernandez AM, Hernandez E, Guerrero-Gomez D, Miranda-Vizuete A, Torres Aleman I. A network of insulin peptides regulate glucose uptake by astrocytes: Potential new druggable targets for brain hypometabolism. Neuropharmacology. 2018;136(Pt B):216-22. 
68. Katsouri L, Birch AM, Renziehausen AWJ, Zach C, Aman Y, Steeds H, Bonsu A, Palmer EOC, Mirzaei N, Ries $\mathrm{M}$, et al. Ablation of reactive astrocytes exacerbates disease pathology in a model of Alzheimer's disease. Glia. 2019. 10.1002/glia.23759.

69. Baik SH, Kang S, Son SM, Mook-Jung I. Microglia contributes to plaque growth by cell death due to uptake of amyloid beta in the brain of Alzheimer's disease mouse model. Glia. 2016;64(12):2274-90.

70. Grathwohl SA, Kalin RE, Bolmont T, Prokop S, Winkelmann G, Kaeser SA, Odenthal J, Radde R, Eldh T, Gandy $S$, et al. Formation and maintenance of Alzheimer's disease [beta]-amyloid plaques in the absence of microglia. Nat Neurosci. 2009;12(11):1361-3.

71. Sosna J, Philipp S, Albay R 3rd, Reyes-Ruiz JM, Baglietto-Vargas D, LaFerla FM, Glabe CG. Early longterm administration of the CSF1R inhibitor PLX3397 ablates microglia and reduces accumulation of intraneuronal amyloid, neuritic plaque deposition and pre-fibrillar oligomers in 5XFAD mouse model of Alzheimer's disease. Mol Neurodegener. 2018;13(1):11.

72. Pitt J, Wilcox KC, Tortelli V, Diniz LP, Oliveira MS, Dobbins C, Yu XW, Nandamuri S, Gomes FCA, DiNunno N, et al. Neuroprotective astrocyte-derived insulin/insulin-like growth factor 1 stimulates endocytic processing and extracellular release of neuron-bound Abeta oligomers. Mol Biol Cell. 2017;28(20):2623-36.

73. Belyaev ND, Kellett KA, Beckett C, Makova NZ, Revett TJ, Nalivaeva NN, Hooper NM, Turner AJ. The transcriptionally active amyloid precursor protein (APP) intracellular domain is preferentially produced from the 695 isoform of APP in a \{beta\}-secretase-dependent pathway. J Biol Chem. 2010;285(53):41443-54.

74. Jaeger LB, Dohgu S, Hwang MC, Farr SA, Murphy MP, Fleegal-DeMotta MA, Lynch JL, Robinson SM, Niehoff ML, Johnson SN, et al. Testing the neurovascular hypothesis of Alzheimer's disease: LRP-1 antisense reduces blood-brain barrier clearance, increases brain levels of amyloid-beta protein, and impairs cognition. J Alzheimers Dis. 2009;17(3):553-70.

\section{Figures}


A

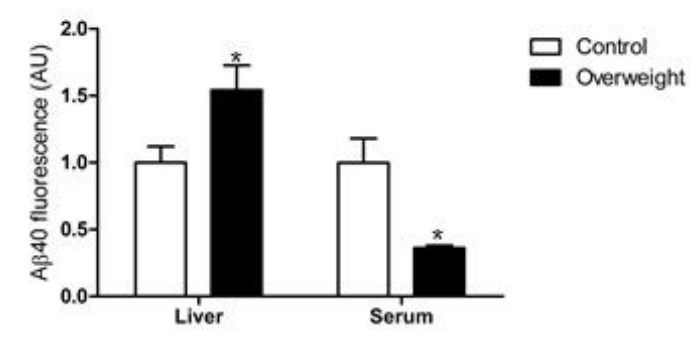

B

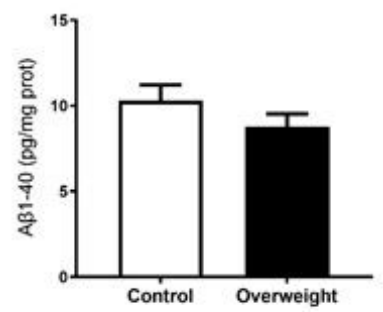

Figure 1

\section{Figure 1}

Diet modulates peripheral $A \nabla$ uptake. $A$, Overweight mice show enhanced $A \nabla$ uptake by the liver and lower serum $A \nabla$ levels $(n=4)$. B, Brain $A \nabla$ levels remain unaltered in overweight mice $(n=6-8) .{ }^{*} p<0.05,{ }^{*} p<0.01$, and $* * * p<0.001$ in this and following figures. 
A

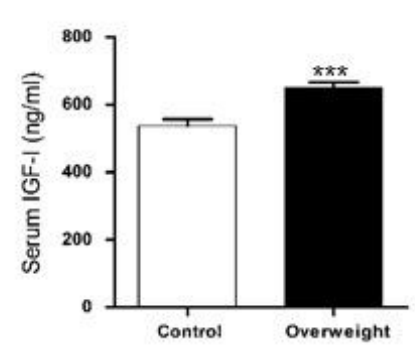

C

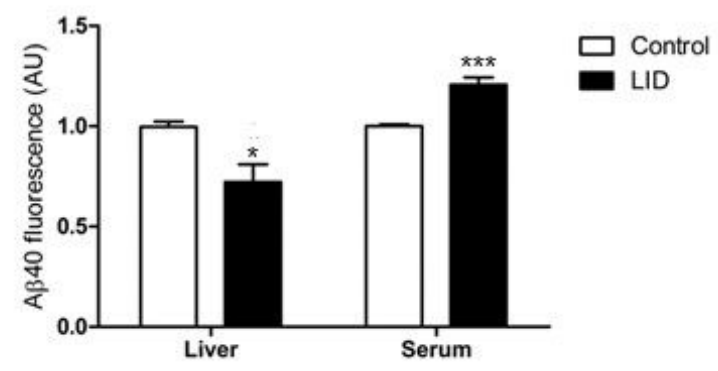

Figure 2
B
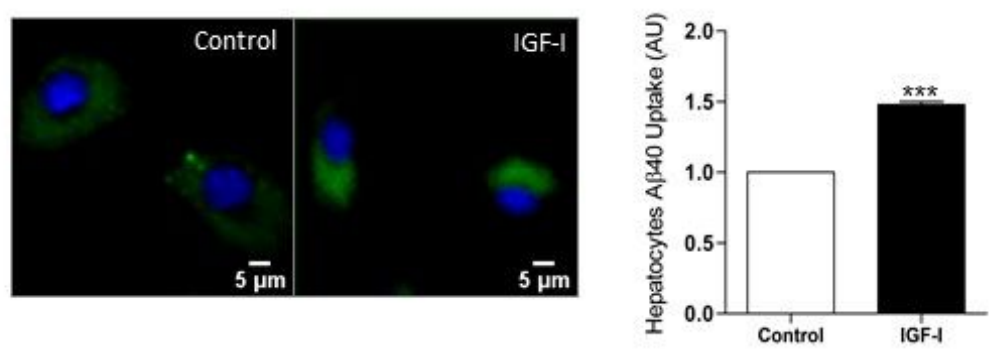

D

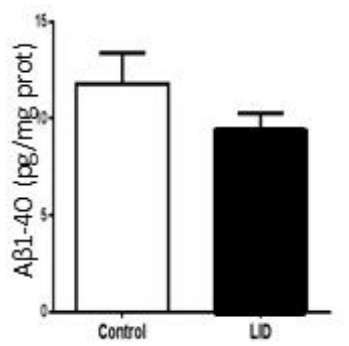

\section{Figure 2}

Modulation by IGF-I of AD uptake by hepatocytes. A, Serum levels of IGF-I are increased after 10 weeks of

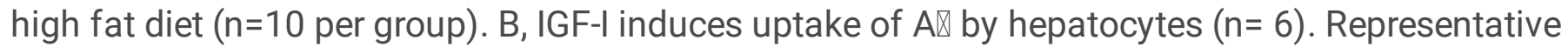
micrograph of cultured hepatocytes with internalized fluorescent $A \rrbracket$ (green). Cell nuclei stained with

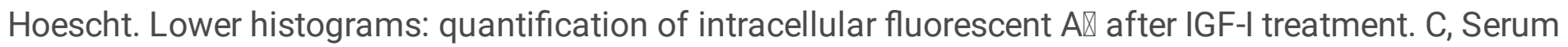
IGF-I deficient mice (LID mice) show reduced $A \rrbracket$ uptake by the liver $(n=5$ control 6 LID). D, Brain $A \rrbracket$ levels did not change in LID mice $(n=8)$. 
A
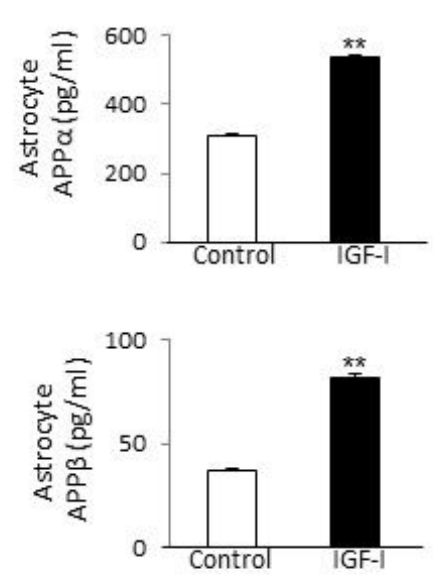

C

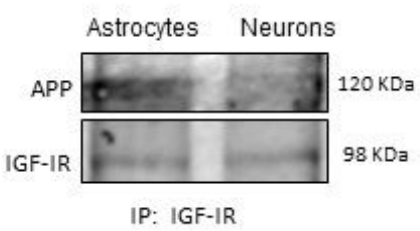

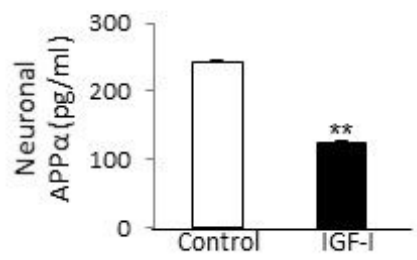

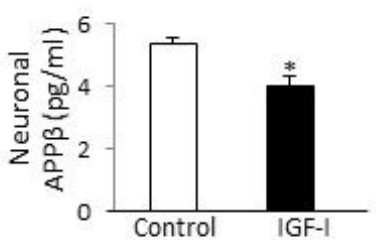

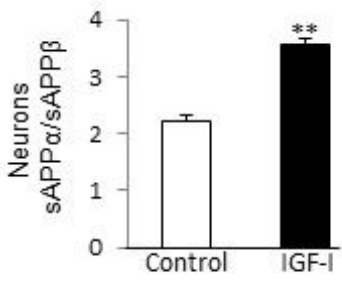

B

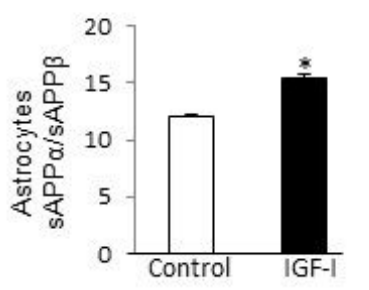

D

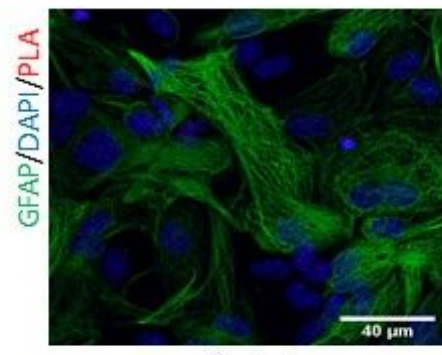

Control

Figure 3

\section{Figure 3}

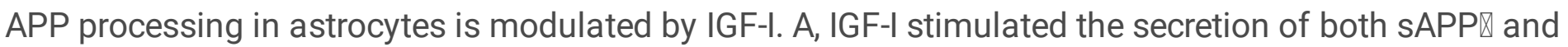
SAPP $\triangle$ in cultured astrocytes (left histograms), while inhibited it in neurons (righ histograms, $n=4$ ). $B$, However, IGF-I increased the SAPP $/$ /SAPP $₫$ ratio in both cell types, indicating a net non-amyloidogenic action of IGF-I in these cells. C, IGF-IR and APP co-immunoprecipitate in cultured astrocytes while in neurons the interaction is negligible. D, Proximity ligation assays (PLA) of APP and IGF-IR in cultured astrocytes confirm an interaction of both proteins that is upregulated by IGF-I $(n=3)$. Cell nuclei stained with Hoescht. 
A
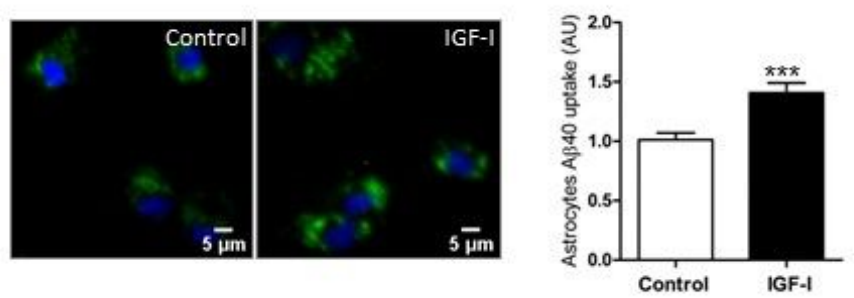

B

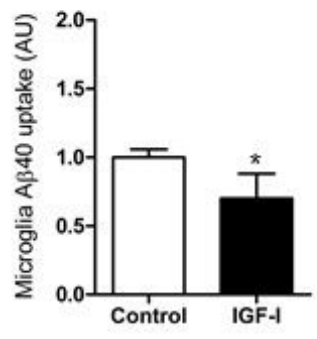

C

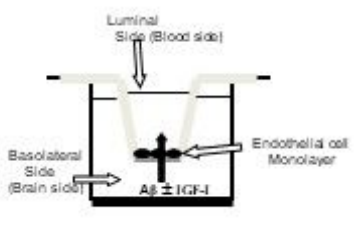

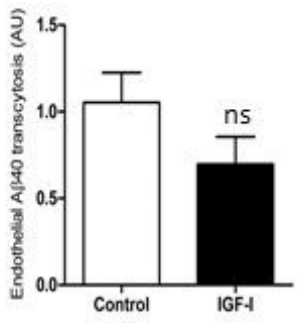

Figure 4

\section{Figure 4}

IGF-I modulates brain $A \rrbracket$ uptake in a cell-specific manner. $A, A \rrbracket$ uptake by astrocytes is significantly increased by IGF-I $(n=8)$. Representative photomicrograph showing uptake by cultured astrocytes of fluorescently labeled $A \rrbracket$ (green). Cell nuclei stained with Hoescht. $B, A \rrbracket$ uptake by microglia is significantly reduced by IGF-I $(n=7)$. C, IGF-I did not significantly affect brain-to-blood efflux in an in vitro system mimicking the blood-brain-barrier (cartoon in the left). Amount of $A \rrbracket$ in the upper chamber was quantified $15 \mathrm{~h}$ after adding it to the lower chamber in the presence or absence of IGF-I $(n=6)$. 
A

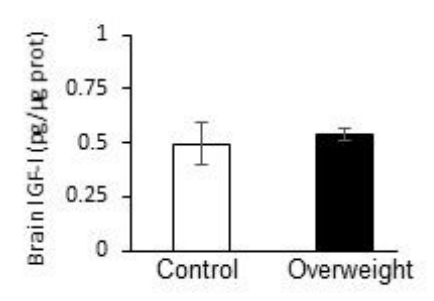

B
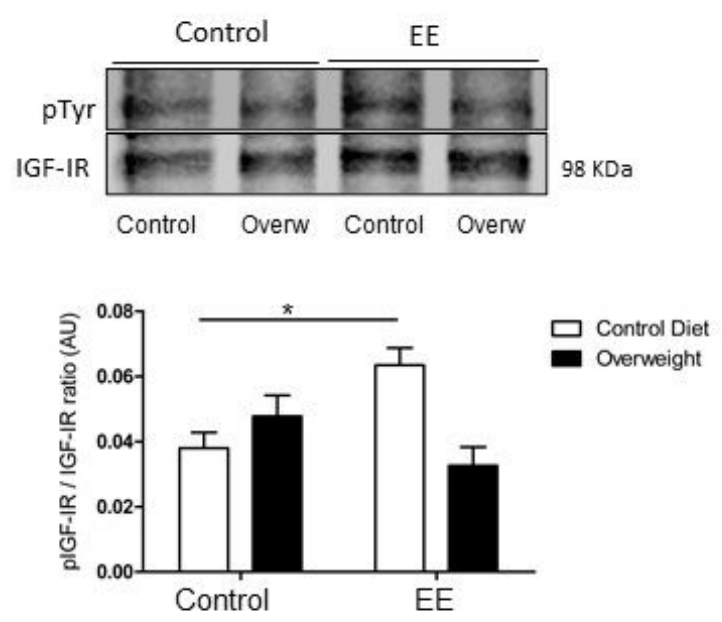

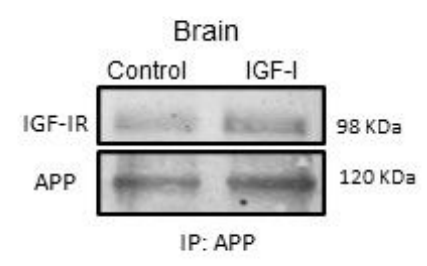

D
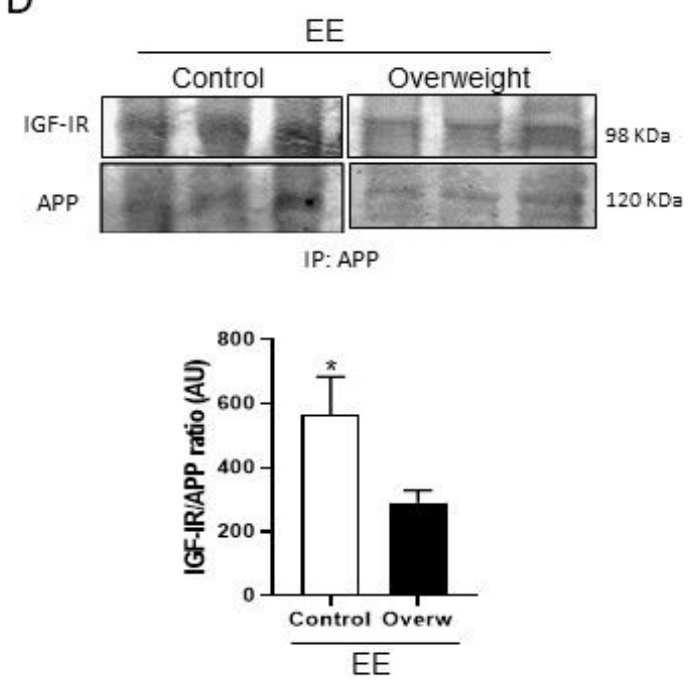

Figure 5

\section{Figure 5}

Reduced entrance of serum IGF-I in overweight mice. A, Brain levels of IGF-I were normal in HFD-fed overweight mice ( $n=10$ per group). $B$, In response to environmental enrichment (EE), overweight mice show lower brain IGF-IR phosphorylation than lean mice receiving a standard diet. Representative blot is shown, together with quantification histograms ( $n=10 \mathrm{EE} / 6$ Control; for each diet). C, Brain IGF-IR/APP co-immunoprecipitation is increased after systemic IGF-I administration. D, Interaction of APP with IGF-IR in the brain of mice submitted to EE stimulation was significantly decreased in overweight mice $(n=10$ per group).

\section{Supplementary Files}

This is a list of supplementary files associated with this preprint. Click to download.

- SupplFig.jpg 